\title{
Internal Auditors' Characteristics and Audit Fees: Evidence from Egyptian Firms
}

\author{
Dalia A. Abbass ${ }^{1} \&$ Mahmoud M. Aleqab ${ }^{2}$ \\ ${ }^{1}$ College of Commerce, Damietta University, New Damietta, Egypt \\ ${ }^{2}$ College of Business Administration, Prince Sultan University, Riyadh, Kingdome of Saudi Arabia \\ Correspondence: Dalia A. Abbass, College of Commerce, Damietta University, New Damietta 3451, Egypt. Tel: \\ 966-5-6835-9266. E-mail: daliaadel2000@yahoo.com
}

Received: January 31, 2013

Accepted: March 5, $2013 \quad$ Online Published: March 11, 2013

doi:10.5539/ibr.v6n4p67

URL: http://dx.doi.org/10.5539/ibr.v6n4p67

\begin{abstract}
Reliance of external auditors on the work of internal auditors is very important but yet, complex decision tasks that require professional judgment as it is influenced by a number of factors, characteristics of internal auditors are of the most important factors to be considered. The paper obtains various criteria relating to the evaluation of internal audit organizational status, work performed, competence, and professional due care as stipulated in Professional Auditing Standards including the Egyptian Auditing Standard (EAS)No.610 "Using the work of internal auditors". This study revealed that internal auditors' characteristics assist in increasing external auditors' reliance on their works and so minimize external auditors' efforts and so fees. Data on internal audit characteristics are obtained from survey respondents of Egyptian companies and audit fee data are obtained from their annual reports. Results indicate that lower external audit fees are associated with top management support for internal auditors, not imposing constraints on internal auditors works, is ready to act upon internal audit staff findings and recommendations, adequacy of education of internal auditors, good practices for hiring and training internal auditors. Also, lower external audit fees are associated with adequacy of working paper documentation supporting internal auditors' conclusions, sufficiency of internal auditors' evidences.
\end{abstract}

Keywords: internal auditing, reliance on internal auditing, audit fees, characteristics of internal auditors, Egyptian Auditing Standard (EAS) 610

\section{Introduction}

For many years, external auditors can choose to rely on the works of internal auditors in performing their audit. Auditing standards recognize that this reliance can be directly as assistants under the supervision of the external auditors or indirectly by performing independent work upon which the external auditor can rely (SAS 65; IAS 604). This can achieve enhanced audit efficiency without a loss of effectiveness (PCAOB, 2007b) and in the same time minimize fees as reliance on internal auditors work can reduce the evidence collected directly by the external auditors, which decreases external audit fees. This paper discusses the professional auditing standards in general and the Egyptian Auditing standards in particular that relate to this reliance as well as related research finding. On the basis of these analyses and findings, certain criteria are developed for evaluating the characteristics of internal auditors as an indicator for quality and so the extent of relying on their work and its effect on audit fees.

Previous studies discussed three internal auditor characteristics; quality factors of competence, objectivity, and quality of work performed (Zulkifflee et al., 2012; DeZoort, Houston, \& Peters, 2001; Grambling, 1999), without determining the relative importance of these three factors which is expected to differ. (Krishnamurthy, 2001; Maletta \& Kida, 1993; Margheim, 1986), Suggesting that there is a direct relationship between external auditors' reliance on internal auditors and the quality of their characteristics (Abdel-khalik et al., 1983; Brody et al., 1998; Maletta, 1993; Schneider, 1985). So, it is very important to know how internal auditors characteristics as determined by professional auditing standards (e.g. ISA 610 and its amendments; SAS 65, EAS No. 610), namely internal auditors' objectivity, competence, and work performance affect external auditors' evaluation of an internal audit function's quality and so the extent of reliance. Findings indicate that the greater the objectivity, technical competence and quality of work performance (i.e. the exercise of due professional care), the greater the 
potential for internal auditors to contribute to the external audit and so the lower the audit fees.

In Egypt, Dr. Mahmoud Mohee Eldeen, the former minister of investment issued a ministerial decree no. 166 of 2008 regarding issuing the Egyptian Auditing Standards and Limited Reviews of historical Financial Information which replaces the Egyptian Auditing Standards that were issued in 2000. The standards issued according to the ministerial decree were 38 standards. A general framework was presented to complete the Egyptian Auditing Standards and to make it consistent with the International Auditing Standards.

These standards include Egyptian Auditing Standard (ESA NO. 610), Using the Work of Internal Auditors, which aims at setting the standards and guidelines for external auditors when they study their reliance on the work of (IA). Auditing procedures included in this standard are applied only to internal auditing activities that relate to financial statements audits. The requirements of this standard re-emphasize the importance of the IA function and its role in enhancing the quality of the audit process, keeping in mind that the external auditor bears full responsibility for expressing an audit opinion.

While the roles of internal auditors differ from external auditors, they can coordinate and cooperate their efforts that can yield collective outcomes, such as higher quality audits and economic benefits. In fact, professional auditing standards recognize the potential contribution that internal auditors can provide to external auditors (SAS No. 65, AICPA, 1991; ISA No. 610; PCAOB, 2007, EAS No.610). This contribution can be made indirectly when internal auditors assist external auditors or directly when internal auditors perform various audits and reviews throughout the audit year on which the external auditors may rely (SAS No. 65, AICPA, 1991; Maletta, 1993). However, an important factor in considering of the use of IA is the quality of IA. Both professional auditing standards and prior studies interpret IA quality as specific characteristics of both the organization and the parties performing IA activities (e.g., objectivity of IA staff, competency, professional due care, and independence) and external auditors are to first consider these characteristics before relying on the work of the internal auditor. (see SAS No. 65, AICPA, 1991; ISA No. 610, MIA, 2000; Felix, Gramling \& Maletta, 2001; IIA 2009; Prawitt, Smith \& Wood, 2009)

This paper studies the relationship between different IA characteristics of Egyptian firms and external audit fees. While most of previous studies on this relationship have been researched in the U.S., there is little evidence from different environments like Arab countries context. So, it is important to have evidence from different environments to enrich the internal auditing literature and enhance our understanding about the importance and role of IA, within the light of their characteristics (Jaggi \& Leung, 2007), in minimizing audit fees especially with the globalization of auditing standards (including internal auditing). Research based on US firms may not be applicable to Egyptian firms as business and institutional environments as well as ownership structure of firms from Egypt must differ from those of the U.S. firms.

The purpose of this paper is to evaluate the extent to which characteristics of internal auditors including organizational status/objectivity, work scope, competency, and due professional care will influence external auditors reliance on their works and so will increase/decrease audit fees. This gives rise to the following question: How different characteristics of internal auditors affect external auditors' reliance on their works and so audit fees?

Our motivation for studying this relationship is that professional auditing standards encourage internal auditors to work closely with the external auditor. The Egyptian Auditing standard on (ESA No.610) indicates "external auditor should consider internal audit department activities and their effect, if any, on external audit procedures" (EAS No. 610, 2008).

Another motivation is the mixed results of the few studies that directly examine the relationship between internal audit characteristics and external audit fees (Sandra \& Marion, 2010). Some studies find that IA assistance is not a significant determinant of external audit fees for either financial services clients or industrial firm clients (Stein, Simunic, \& O'Keefe, 1994). Other research finds a direct relationship between the internal audit budget (Carcello, Hermanson, \& Raghunandan, 2005) and the external auditor reliance on the work of internal auditors from one side (Goodwin-Stewart \& Kent, 2006a) and audit fees from the other side. The conflicting results of prior research suggest that there is room for more research on the relationship between internal auditors' characteristics and external audit fees.

Consistent with expectations, We find that the following IA characteristics are associated with lower external audit fees: (1) management is ready to act upon internal audit staff findings and recommendations, (2) education of internal auditors is adequate, (3) practices for hiring and training internal auditors are satisfactory, (4) working 
paper documentation to support the internal auditors' conclusions are adequate, and (5) internal audit evidences are sufficient.

This paper provides evidence that internal auditors characteristics affect external audit fees in Egyptian listed firms.

The remainder of this paper is as follows: First: background and hypothesis development will be discussed. Then, the methods used to collect the data will be described, followed by the results. Finally, the results will be discussed as well as the opportunities for future research.

\section{Background and Hypothesis Development}

\subsection{Internal Audit and Audit Fees}

Few studies have examined the relation between internal audit and external audit fees and yet with mixed results (Goodwin et al., 2006). Some studies report a negative relation between audit fees and the contribution of internal audit to the external audit (Elliott \& Korpi, 1978) and Felix et al., 2001) because of the increased reliance of external auditors on internal auditors work and so lowering audit fees. Other studies find no significant relationship between audit fees and the level of internal audit contribution (Carey et al. 2000a, Stein et al., 1994). More surprisingly, some studies find that fees are higher when companies use internal audit, suggesting that internal and external audit are regarded as complementary means of increasing overall monitoring (Carey et al., 2000a; Hay \& Knechel, 2002). This is consistent with a broader role of internal audit, which in recent years has evolved from a narrow focus on control to embrace risk management and corporate governance (Brody \& Lowe, 2000; Carey et al., 2000; Leung et al., 2004).

\subsection{External Auditor Reliance on Internal Auditors}

The extent to which an external auditor should rely on the work of others including the internal auditors depends partly on the agents performing the work (e.g., the IAs' competence including formal education, training, experience, funding), and objectivity (e.g., as demonstrated by the organization of the internal audit department, reporting channels etc.; AS 5: PCAOB, 2007a). EAS 610 requires external auditors to evaluate four factors when considering the adequacy of internal auditors work. These factors are objectivity, technical competence, due professional care and work scope (EAS No. 610, 2010). This is consistent with the requirements of the current US standards that external auditors should consider the competency, objectivity and work performed by internal auditors when making reliance decisions (AICPA, 2008, AU Section 322; PCAOB, 2007).

\subsection{Evaluating the Internal Audit Function}

International Standard on Auditing (ISA) NO.610 and ESA No. 610 stated that the external auditor shall determine whether he can depend on the work performed by the internal audit function for purposes of the audit by evaluating the extent to which the internal audit function's organizational status, reporting and communication channels support the objectivity of the internal auditors; the level of competence of the internal auditor; scope of work performed and due professional care (ISA,610 revised 2012 Para. A5-A9). Otherwise, the external auditor shall not use the work of the internal audit function (ISA,610 revised 2012 Para. Para. A12-A14).

The following sections discuss the assessments of internal auditor's organizational status, competence, work scope and due professional care after first providing information about the criteria for these assessments.

\subsubsection{Criteria to Evaluate Extent of EA Reliance on IA}

External auditors have to take into their consideration certain criteria when obtaining an understanding of and evaluating the internal audit function. Egyptian Auditing Standard (ESA) NO. 610, determines certin criteria for external auditors when they consider their reliance on the work of (IA). Table 1 identifies the various sources of information and categorizes these sources according to usefulness for evaluating internal auditors organizational status, work scope, competency, and due professional care and categorizes these sources according to usefulness for evaluating internal auditors' competence, objectivity, and work scope. 
Table1. Criteria for evaluating internal audit organizational status, competency and due professional care

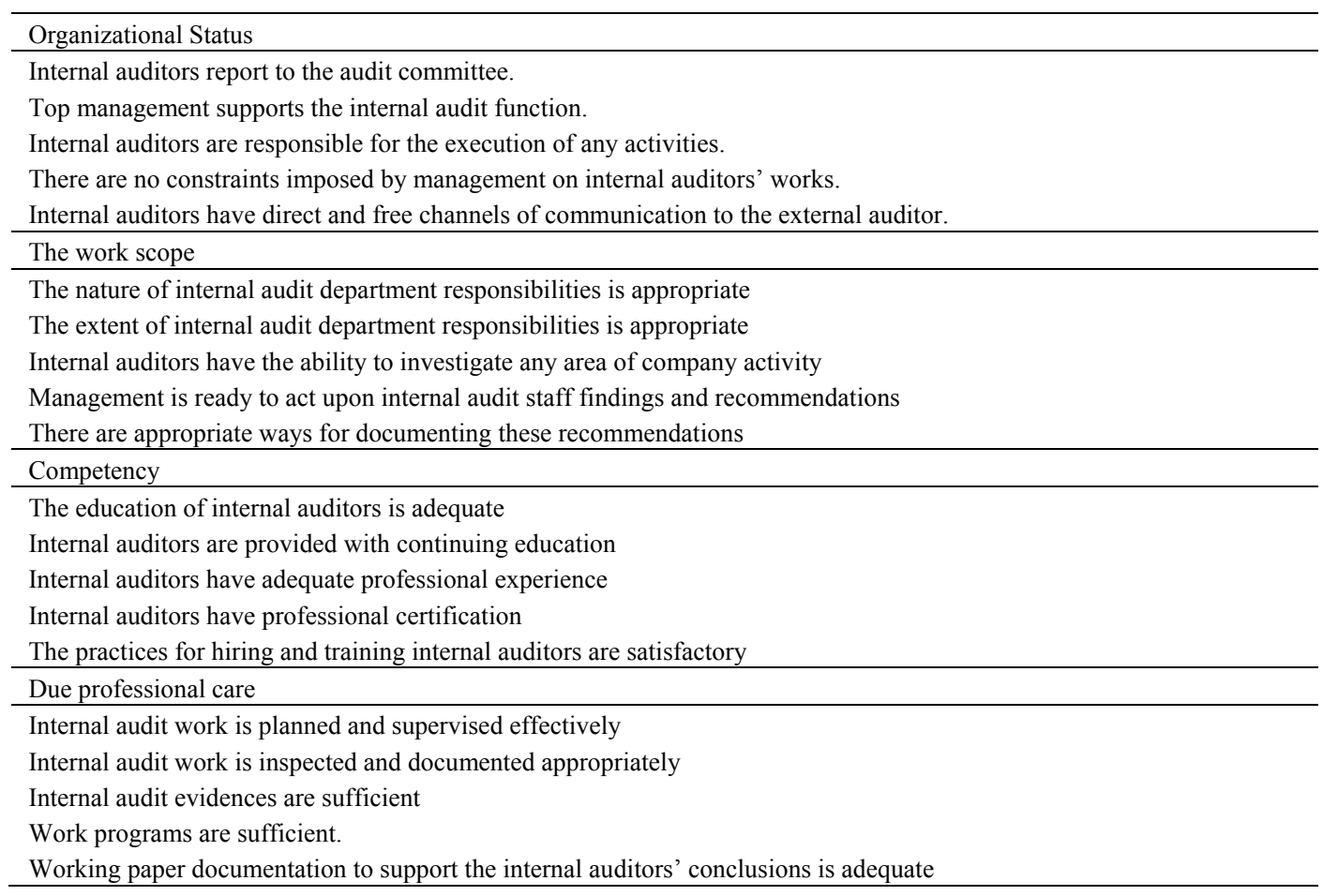

\subsubsection{Evaluating Internal Auditors' Organizational Status/Objectivity}

In assessing internal auditors' organizational status, the external auditor should consider the internal audit activities status in the organizational structure and the corresponding effect on its objectivity (EAS No. 610, 2010, Schneider, 2010). This section discusses the criteria required for assessing internal audit organizational status provided by the Treadway Commission, SAS No. 65, ESA No.610, ISA No. 610 and Institute of Internal Auditors (IIA) Standards.

There are three principal factors that should be considered when determining the internal audit organizational status and so objectivity: the organizational positioning of the internal audit function, the development capabilities internal auditor and the internal audit reporting relationships. (Schneider, 2010, p.98). Of the three, the internal audit reporting relationships are the most important consideration when evaluating the objectivity of the internal audit function (Clark et al., 1980, Brown, 1983, Messier \& Schneider, 1988). Generally speaking, the reporting level should be sufficient to ensure that internal audit findings are taken seriously. For day-to-day operations, the chief internal auditor should report administratively to the highest management level not directly involved in preparing the company's financial statements (Treadway Commission, 1987, p. 38, AICPA, 2007, p. 1 EAS No. 610, p.7). This includes having direct, unrestricted access and regular reporting to the board of directors, audit committee, or owner-manager, to the extent that he should attend all audit committee meetings (The external auditor can assess this through the frequency of internal auditors' communications with the company's board of directors or its audit committee and whether these communications are censored by management) (SAS No. 65, Treadway Commission, 1987, p. 39). He should also be able to meet with the committee regularly and should have free channels of communication with the external auditor (ESA No. 610, p.7).

Internal auditors must be able to maintain objectivity and identify threats to their organizational status / objectivity and they are required to evaluate and minimize those threats, and determine whether they can be objective given the steps they have taken to minimize the threats identified. This is largely a process of self-assessment by internal auditors. (IIA 2000, 2003, p.224). So, internal auditors are prohibited from auditing areas where there is any personal or professional involvement with or allegiance to the area being audited, or where relatives are employed in important or audit-sensitive positions. They are also prohibited from auditing areas where internal auditors were recently assigned or will be assigned in the future (SAS No. 65). It would also be a conflict of interest to provide assurances services for an activity for which the internal auditor had responsibility within the previous year (IIA, 2003, sec. 1130.A1). This ensures that there will be no appearance 
of bias resulting from auditing relatives or auditing their own work. Schneider, 2010, p.98). Moreover, they should not assume any operational responsibility, be rotated on staff assignments periodically whenever practicable, do not accept gifts or favors from others such as employees, clients, or business associates. These are not only intended to prevent intentional bias on the part of internal auditors, but will avoid instances of unintentional bias as in the case of accepting a small gift from an employee would probably not cause an internal auditor to consciously change a decision, but could result in an unintentional bias toward the employee for which the internal auditor may not be aware.

From the previous discussion, we can specify the following hypothesis:

\section{H1: External auditors will rely more on internal auditors when they are objectivive and this will decrease audit fees.}

Organizational Status

Internal auditors reports to the audit committee.

Top management supports the internal audit function.

Internal auditors are responsible for the execution of any activities.

There are no constraints imposed by management on internal auditors' works.

Internal auditors have direct and free channels of communication to the external auditor.

\subsubsection{Work Scope}

EAS No. 610 specifies that the external auditor should consider the nature and extent of internal auditors work, whether management responds to internal auditors recommendations, and how this is documented when they have decided to rely on their work. This leads to evaluating the following criteria:

From the previous, we can specify the following hypothesis:

\section{H2: External auditors will rely more on internal auditors when there is appropriate work scope and this will decrease audit fees.}

The work scope

The nature of internal audit department responsibilities is appropriate.

The extent of internal audit department responsibilities is appropriate.

Internal auditors have the ability to investigate any area of company activity.

Management is ready to act upon internal audit staff findings and recommendations.

There are appropriate ways for documenting these recommendations.

\subsubsection{Competence}

Competence means having the intelligence, education, and training to be able to add value through performance. Competence comes from "long and intensive preparation, including instruction in skills and methods as well as scholarly principles underlying the skills and methods," and the commitment to "continued study"(Jane 2003) The EA evaluation of the level of competence of the IA function (Ref: Para. A27-A29) determines the nature and extent of the external auditor's audit procedures. The most important two considerations when assessing internal auditors' competence are the characteristics relating to both internal auditors' personal qualifications and the operations of the internal audit function. Individual auditor characteristics are more important in terms of assessment than the characteristics involving how well the internal audit department operates. The reason behind this is the fact that when external auditors evaluate internal auditing on recurring engagements, they will likely need to re-assess internal auditors' personal qualifications more than characteristics relating to internal audit department operations as internal audit personnel will probably change more often than internal audit operations (SAS No. 65).

The personal qualifications include education level, continuing education, professional experience (Messier \& Schneider, 1988), certification as Certified Internal Auditor designation is considered the most important criterion of competence (Myers \& Gramling, 1997) besides educational background of the IA (Reinstein, Lander, \& Gavin, 1994), training programs (Brown, 1983), and performance evaluations of individual internal auditors. At the very top is the chief internal auditor who should be an experienced executive in the necessary business fields to work effectively with companion senior officers, preferably with a background in auditing or a related field, and he should have (Treadway Commission, 1987, p. 38)." 
With regard to competence, we expect that external auditors are more likely to rely on the work of internal auditors when they are more competent.

From the previous discussion, we can specify the following hypothesis:

H3: External auditors will rely more on internal auditors when they are competent and this will decrease audit fees.

\section{Competency}

The education of internal auditors is adequate.

Internal auditors are provided with continuing education.

Internal auditors have adequate professional experience.

Internal auditors have professional certification.

The practices for hiring and training internal auditors are satisfactory.

\subsubsection{Due Professional Care}

Due care is the result of the fact that professional standards are generated "by force of organization or concerted opinion" (Jane 2003). For the external auditor to rely on the work of internal auditors, the internal auditor should plan, supervise, inspect and document their works. Also, whether there should be enough audit evidences, work programs, and papers. So, the internal auditor should exercise due professional care by taking into account the needs of the external auditors in addition to their expectations, including the nature, relative complexity and extent of work needed, and the expected savings in audit fees. This also includes considering the use of data analysis techniques and other computer-assisted audit tools (CBOK, 2007) for better achievement of their works.

In this context, we expect that auditors will rely more on the work of internal auditors when they exert due professional care.

From the previous discussion, we can specify the following hypothesis:

H4: External auditors will rely more on internal auditors when they exert due professional care and this will decrease audit fees.

\section{Due professional care}

Internal audit work is planned and supervised effectively.

Internal audit work is inspected and documented appropriately.

Internal audit evidences are sufficient.

Work programs are sufficient.

Working paper documentation to support the internal auditors' conclusions is adequate.

We can conclude by saying that internal auditing is clearly a profession and value-adding and effective assurance services offered by internal auditors require objectivity, competence, and the use of due care collectively.

\section{Methodology and Data Statistics Analysis}

Data in this study were obtained from survey questionnaires and publicly available information. A survey questionnaire was developed and tested with two auditors' professors and two practicing auditors to ensure that the questions were appropriate. After incorporating changes, one of these changes was to add a question related to the extent of application of EAS No. 610 in Egyptian Listed Companies. The survey data consist of matching responses to questions that were designed for the head of the IA department. A total of 380 questionnaire packages containing a covering letter, the survey and reply pre-paid addressed envelopes were mailed to the head of the IA department of the publicly listed companies on the Egyptian Exchange in 2010. Subsequently, the head of the IA departments were requested to enclose the name of partners who were in charge of their audits. Once the names of partner and public accounting firms were identified, the matching questionnaire for external auditors was sent. Audit fee data are hand-collected from annual reports for the responded firms. A total of 78 completed questionnaires from both internal and external auditor respondents were received, yielding a response rate of 20.5 percent.

After decoding and transforming the data into the computer for data processing, the $17^{\text {th }}$ version of the statistical tool SPSS was used to execute data statistical analysis of the field study as follow:

Statistical methods used in the research: 
Reliability and Validity coefficients:

Reliability is intended to give almost the same results list if re-applied to the sample itself again while validity is intended to achieve the objective of the questionnaire.

Descriptive Statistics:

Where mean was calculated and the standard deviation for the questions of the questionnaire within the light of the study sample as follows:

Table 2. Descriptive statistics

\begin{tabular}{lll}
\hline & Mean & Std. Deviation \\
\hline Organizational Status & 2.57 & .550 \\
Internal auditors report to the audit committee. & 2.34 & .530 \\
Top management supports the internal audit function. & 1.68 & .677 \\
Internal auditors are responsible for the execution of any activities. & 2.96 & .474 \\
There are no constraints imposed by management on internal auditors' works. & 1.79 & .639 \\
Internal auditors have direct and free channels of communication to the external auditor. & 2.47 & .721 \\
The work scope & 2.50 & .683 \\
The nature of internal audit department responsibilities is appropriate & 2.13 & .472 \\
The extent of internal audit department responsibilities is appropriate & 2.55 & .598 \\
Internal auditors have the ability to investigate any area of company activity & 3.00 & .816 \\
Management is ready to act upon internal audit staff findings and recommendations & 2.49 & .702 \\
There are appropriate ways for documenting these recommendations & 2.46 & .738 \\
Competency & 2.01 & .622 \\
The education of internal auditors is adequate & 2.00 & .542 \\
Internal auditors are provided with continuing education & 2.18 & .534 \\
Internal auditors have adequate professional experience & 1.93 & .550 \\
Internal auditors have professional certification & 2.33 & .575 \\
The practices for hiring and training internal auditors are satisfactory & 2.53 & .642 \\
Due professional care & 2.04 & .528 \\
Internal audit work is planned and supervised effectively & 2.93 & .660 \\
Internal audit work is inspected and documented appropriately & 2.92 & .688 \\
Internal audit evidences are sufficient & 2.92 & .583 \\
Work programs are sufficient. & 2.79 & .805 \\
Working paper documentation to support the internal auditors' conclusions is adequate & 2.95 & .728 \\
\hline
\end{tabular}

\section{Correlation:}

Pearson correlation coefficient was used to measure the strength and type of relationship between variables, whether it is proportional or verse.

\section{Regression:}

Stepwise regression, used to test the relationship between a dependent variable and one independent variable. A determinant coefficient was used to measure the ability of independent variables to explain the changes in the dependent variable.

\subsection{Reliability and Validity Coefficients}

The reliability coefficient (Cronbach's Alpha) for the questionnaire questions was calculated to investigate the extent to which the results of the field study could be are reliable.

Since all the questions acquire likert scale, the reliability and validity coefficients of the study variables were calculated. In table 3 it is clear that figures of reliability and validity coefficient are reasonable for all variables. The questionnaire included two main variables, the reliability coefficient ranged from 0.641 for " Competence " to 0.839 for "work scope", while the validity coefficient ranged from 0.801 to 0.916 respecively (the value of validity coefficient is the square root of the reliability coefficient).

It could be said that it is a coefficient with good significance for research aims, and that they meet the objectives of the study. 
Table 3. Reliability and valiadtiy coefficients of the measurements used in the questionnaire

\begin{tabular}{lll}
\hline Variables & Cronbach's alpha & Valiadtiy \\
\hline Characteristics of Internal Auditors & 0.932 & 0.965 \\
Organizational Status & 0.749 & 0.865 \\
Work Scope & 0.839 & 0.916 \\
Competence & 0.641 & 0.801 \\
Due Professional Care & 0.677 & 0.823 \\
\hline
\end{tabular}

\subsection{Sample Description According to Personal Variables}

In this section the sample of the study will be described according to personal variables as follow:

Table 4 shows that from the descriptive analysis, it can be seen that $52.6 \%$ of the sample are males, while the rest are females. In addition, most of the candidates aged between 30 to 40 and 40 to 50 , representing $36.8 \%$ and $32.9 \%$ of the sample, respectively.

As it can be seen from Table 2 most of the sample has bachelor degree representing 48.7\%. Most of the sample has ten to fifteen years of experience representing almost $31.6 \%$ of the study sample.

Table 4. Study sample descriptive analysis

\begin{tabular}{llll}
\hline Variable & & Frequency & Percentage (\%) \\
\hline Gender & Male & 40 & 52.6 \\
& Female & 36 & 47.4 \\
\hline Age & Less than 30 years & 10 & 13.2 \\
& 30-40 years & 28 & 36.8 \\
& 40-50 years & 25 & 32.9 \\
& 50 years or higher & 13 & 17.1 \\
\hline Education Level & Secondary school or below & 6 & 7.9 \\
& Bachelor & 37 & 48.7 \\
& Diploma & 18 & 23.7 \\
\hline Experience & Master or higher & 15 & 19.7 \\
\hline & Less than 5 years & 11 & 14.5 \\
& 5-10 years & 22 & 28.9 \\
& 10-15 years & 24 & 31.6 \\
\hline
\end{tabular}

\subsection{Testing the Hypothesies}

\section{H1: 'There is no significant relationship between organizational status of internal auditors and audit fees'}

To test this hypothesis we can use Correlation and regression model as follows:

Correlation coefficients:

Table 5 provides the correlation coefficients of the variables used in the multivariate analysis. As it can be seen, the correlation coefficients reported indicate that there is a strong negative correlation between (Top management supporting the internal audit function) and dependent variable (audit fees) where the value of the correlation coefficient is (-.796), it is a significant at the significan level of $1 \%$.

Generally, there is a negative relationship between the dependent variable(Audit Fees) and the independent variables(organizational status), and a significance at significance level $1 \%$.

Table 5. Correlation coefficients between organizational status and audit fees

\begin{tabular}{ll}
\hline organizational status & Audit Fees \\
\hline Internal auditors reports to the audit committee & $-.739^{* *}$ \\
Top management supports the internal audit function & $-.796^{* *}$ \\
Internal auditors are responsible for the execution of any activities. & $-.561^{* *}$ \\
There are not any constraints imposed by management on internal auditors works & $-.646^{* *}$ \\
Internal auditors have direct and free channels of communication to the external auditor & $-.415^{* *}$ \\
The more the strength the organizational status of internal auditors the more the reliance of the external auditor on the & $-.771^{* *}$ \\
works of the internal auditors and so the lower the audit fees & \\
\hline Note: ${ }^{* *}$ Correlation is significant at the 0.01 level (2-tailed).
\end{tabular}


Regression model:

Table 6 represents a The stepwise regression model of independent variables (organizational status of internal auditors) on the dependent variable (Audit fees).

Table 6. The stepwise regression

\begin{tabular}{|c|c|c|c|c|c|}
\hline$F$ & $\mathrm{R}^{2}$ & & & & \\
\hline (P-value) & & & $\mathrm{B}$ & $\mathrm{t}$ & P-value \\
\hline \multirow[t]{5}{*}{$83.856(0.000)$} & 0.825 & Constant & 3.911 & 11.410 & .000 \\
\hline & & $\mathrm{x} 1.1 .2$ & -.322 & -2.709 & .008 \\
\hline & & $\mathrm{x} 1.1 .6$ & -.808 & -7.060 & .000 \\
\hline & & $\mathrm{x} 1.1 .3$ & -.549 & -4.971 & .000 \\
\hline & & $\mathrm{x} 1.1 .4$ & -.579 & -3.106 & .003 \\
\hline
\end{tabular}

It is clear significant regression model as the $\mathrm{F}$ value (83.856) and it is significant at a significan level of $1 \%$ as the value of $(\mathrm{Sig}=0.000)$ is less than the significant level $1 \%$, a significant regression coefficients and constant show through $\mathrm{T}$ test and the value of $\mathrm{p}$-value as it is significant at the significant level $1 \%$, The most important independent variables that affect the dependent variable are:

- Top management supports the internal audit function.

- The more the strength the organizational status of internal auditors the more the reliance of the external auditor on the works of the internal auditors and so the lower the audit fees.

- Internal auditors are responsible for the execution of any activities.

- There are not any constraints imposed by management on internal auditors works.

The determination coefficient is $(0.825)$, which means that the independent variables explain $82.5 \%$ of the changes that occur in the dependent variable (audit fees).

From the above $\mathbf{H 1}$ is incorrect and we accept the alternative hypothesis:

\section{'There is significant relationship between organizational status of internal auditors and audit fees'}

\section{H2: 'There is no significant relationship between the work scope of internal auditors and audit fees'}

To test this hypothesis we can use Correlation and regression model as follows:

Correlation coefficients:

Table 7 provides the correlation coefficients of the variables used in the multivariate analysis. As it can be seen, the correlation coefficients reported indicated that there is a strong negative correlation between (Management is ready to act upon internal audit staff findings and recommendations) and dependent variable (Audit fees) where the value of the correlation coefficient is (-.831), it is a significant at the significan level of $1 \%$.Generally, there is a negative relationship between the dependent variable and the independent variables (The work scope of internal auditors), and a significance at significance level $1 \%$.

Table 7. Correlation coefficients between the work scope of internal auditors and audit fees

\begin{tabular}{ll}
\hline The work scope & Audit Fees \\
\hline The nature of internal audit department responsibilities is appropriate & $-.758^{* *}$ \\
The extent of internal audit department responsibilities is appropriate & $-.662^{* *}$ \\
Internal auditors have the ability to investigate any area of company activity & $-.741^{* *}$ \\
Management is ready to act upon internal audit staff findings and recommendations & $-.831^{* *}$ \\
There are appropriate ways for documenting these recommendations & $-.764^{* *}$ \\
The better the audit scope of internal audit the more the reliance of the external auditor on the works & $-.778^{* *}$ \\
of the internal auditors and so the lower the audit fees. & \\
Note: ** Correlation is significant at the 0.01 level (2-tailed).
\end{tabular}

Regression model:

Table 8 represents a The stepwise regression model of independent variables (The work scope of internal auditors) on the dependent variable (Audit fees). 
Table 8. The stepwise regression

\begin{tabular}{llllll}
\hline $\mathrm{F}$ & $\mathrm{R}^{2}$ & & & & \\
$(\mathrm{P}$-value $)$ & & & $\beta$ & $\mathrm{t}$ & $\mathrm{P}$-value \\
\hline $97.642(0.000)$ & 0.728 & Constant & 4.324 & 24.546 & .000 \\
& & $\mathrm{x} 1.2 .4$ & -.529 & -5.735 & .000 \\
& & $\mathrm{x} 1.2 .6$ & -.321 & -3.143 & .002 \\
\hline
\end{tabular}

It is clear significant regression model as the $\mathrm{F}$ value (97.642) and it is significant at a significan level of $1 \%$ as the value of $(\mathrm{Sig}=0.000)$ is less than the significant level $1 \%$, a significant regression coefficients and constant show through $\mathrm{T}$ test and the value of $\mathrm{p}$-value as it is significant at the significant level $1 \%$, The most important independent variables that affect the dependent variable (Audit fees) are:

- Management is ready to act upon internal audit staff findings and recommendations.

- The better the audit scope of internal audit the more the reliance of the external auditor on the works of the internal auditors and so the lower the audit fees.

The determination coefficientis (0.728), which means that the independent variables explain $72.8 \%$ of the changes that occur in the dependent variable (Audit fees). (Also whatt about the remaining percentage 28.2\%)

From the above $\mathbf{H} \mathbf{2}$ hypothsis is incorrect and we accept the alternative hypothesis:

\section{'There is significant relationship between the work scope of internal auditors and audit fees'}

\section{H3: 'There is no significant relationship between competency of internal auditors and audit fees'}

To test this hypothesis we can use Correlation and regression modle as follows:

Correlation coefficients:

Table 9 provides the correlation coefficients of the variables used in the multivariate analysis. As it can be seen, the correlation coefficients reported indicate that there is a strong negative correlation between (The adequacy of internal auditors educations) and dependent variable (Audit fees) where the value of the correlation coefficient is $(-.832)$, it is a significant at the significan level of $1 \%$. Generally, there is a negative relationship between the dependent variable and the independent variables (Competency of internal auditors), and a significance at significance level $1 \%$.

Table 9. Correlation coefficients between competency of internal auditors and audit fees

\begin{tabular}{ll}
\hline Competency & Audit Fees \\
\hline The education of internal auditors is adequate & $-.832^{* *}$ \\
Internal auditors are provided with continuing education & $-.726^{* *}$ \\
Internal auditors have adequate professional experience & $-.778^{* *}$ \\
Internal auditors have professional certification & $-.756^{* *}$ \\
The practices for hiring and training internal auditors are satisfactory & $-.798^{* *}$ \\
The more the competency of internal auditors the more the reliance of the external auditor on the & $-.748^{* *}$ \\
works of the internal auditors and so the lower the audit fees & \\
Note: ** Correlation is significant at the 0.01 level (2-tailed). &
\end{tabular}

\section{Regression model:}

Table 10 represents a The stepwise regression model of independent variables (Competency of internal auditors) on the dependent variable (Audit fees).

Table 10. The stepwise regression

\begin{tabular}{|c|c|c|c|c|c|}
\hline $\begin{array}{l}F \\
\text { (P-value) } \\
\end{array}$ & $\mathbf{R}^{2}$ & & B & $\mathbf{t}$ & P-value \\
\hline \multirow[t]{4}{*}{$95.341(0.000)$} & 0.799 & Constant & 4.648 & 26.625 & .000 \\
\hline & & $\mathrm{x} 1.3 .1$ & -.564 & -5.929 & .000 \\
\hline & & $\mathrm{x} 1.3 .5$ & -.441 & -4.093 & .000 \\
\hline & & $\mathrm{x} 1.3 .6$ & -.213 & -2.252 & .027 \\
\hline
\end{tabular}


It is clear significant regression model as the $\mathrm{F}$ value (95.341) and it is significant at a significan level of $1 \%$ as the value of $(\mathrm{Sig}=0.000)$ is less than the significant level $1 \%$, a significant regression coefficients and constant show through $\mathrm{T}$ test and the value of $\mathrm{p}$-value as it is significant at the significant level $1 \%$, The most important independent variables that affect the dependent variable (audit fees) are:

- The education of internal auditors is adequate.

- The practices for hiring and training internal auditors are satisfactory.

- The more the competency of internal auditors the more the reliance of the external auditor on the works of the internal auditors and so the lower the audit fees.

The determination coefficientis (0.799), which means that the independent variables explain $79.9 \%$ of the changes that occur in the dependent variable (Audit fees).

From the above $\mathbf{H 3}$ is incorrect and we accept the alternative hypothesis:

\section{'There is significant relationship between competency of internal auditors and audit fees'}

H1d: 'There is no significant relationship between due professional care by internal auditors and audit fees'

To test this hypothesis we can use Correlation and regression model as follows:

Correlation coefficients:

Table 11 provides the correlation coefficients of the variables used in the multivariate analysis. As it can be seen, the correlation coefficients reported indicated that there is a strong negative correlation between (Working paper documentation to support the internal auditors' conclusions is adequate) and dependent variable (Audit fees) where the value of the correlation coefficient is $(-.773)$, it is a significant at the significan level of $1 \%$.Generally, there is a negatively relationship between the dependent variable and the independent variables (Due professional care by internal auditors), and a significance at significance level $1 \%$.

Table 11. Correlation coefficients between due professional care by internal auditors and audit fees

\begin{tabular}{ll}
\hline Due professional care & Audit Fees \\
\hline Internal audit work is planned and supervised effectively & $-.706^{* *}$ \\
Internal audit work is inspected and documented appropriately & $-.684^{* *}$ \\
Internal audit evidences are sufficient & $-.631^{* *}$ \\
Work programs are sufficient. & $-.561^{* *}$ \\
Working paper documentation to support the internal auditors' conclusions is adequate & $-.773^{* *}$ \\
The more the strength the due professional care exerted by internal auditors the more the reliance of the & $-.692^{* *}$ \\
external auditor on the works of the internal auditors and so the lower the audit fees &
\end{tabular}

\section{Regression model:}

Table 12 represents a The stepwise regression model of independent variables (Due professional care by internal auditors) on the dependent variable (Audit fees).

Table 12. The stepwise regression

\begin{tabular}{|c|c|c|c|c|c|}
\hline $\begin{array}{l}\text { F } \\
\text { (P-value) }\end{array}$ & $\mathbf{R}^{2}$ & & B & $\mathbf{t}$ & P-value \\
\hline \multirow[t]{4}{*}{$47.504(0.000)$} & 0.664 & Constant & 3.655 & 16.064 & .000 \\
\hline & & $\mathrm{x} 1.4 .5$ & -.559 & -4.48 & .000 \\
\hline & & $\mathrm{x} 1.4 .3$ & -.492 & -3.47 & .000 \\
\hline & & $\mathrm{x} 1.4 .6$ & -.455 & -3.08 & .002 \\
\hline
\end{tabular}

It is clear significant regression model as the $\mathrm{F}$ value (47.504) and it is significant at a significan level of $1 \%$ as the value of $(\mathrm{Sig}=0.000)$ is less than the significant level $1 \%$, a significant regression coefficients and constant show through $\mathrm{T}$ test and the value of $\mathrm{p}$-value as it is significant at the significant level $1 \%$, The most important independent variables that affect the dependent variable are:

- Working paper documentation to support the internal auditors' conclusions is adequate. 
- Internal audit evidences are sufficient.

- The more the strength the due professional care exerted by internal auditors the more the reliance of the external auditor on the works of the internal auditors and so the lower the audit fees.

The determination coefficientis (0.664), which means that the independent variables explain $66.4 \%$ of the changes that occur in the dependent variable (Audit fees).

From the above H1d is incorrect and we accept the alternative hypothesis:

'There is significant relationship between due professional care by internal auditors and audit fees'

From the above the first hypothesis is incorrect and we accept the alternative hypothesis:

\section{'There is significant relationship between characteristics of internal auditors and audit fees'}

\section{Conclusions and Implications}

The results of this study indicate that certain internalauditors' characteristics are significant determinants of external audit fees. Specifically, in terms of IA characteristics, internal audit organizational status, work performed, competence, and professional due care larger internal are associated with lower audit fees. Specfically, the more management is ready to act upon internal audit staff findings and recommendations, the better the education of internal auditors, the more the practices for hiring and training internal auditors are satisfactory, the more the adequacy that working paper documentation support the internal auditors' conclusions, and the more the suffciency of internal audit evidences, the lower the auditt fees.

This study provides further evidence to support the linkage between external audit fees and internal audit characteristics. The fndings of this study is consistent with Sandra and Hutchinson (2010) which showed that certain IA characteristics and work performed are important determinants of external audit fees. Specifically, in terms of IA characteristics, they found that larger internal audit departments are associated with lower audit fees. The results of ttheir study provides support to the international auditing standards requirement of external auditors assessing the activities of internal auditing and their impact on external audit procedures, and on the co-ordination of external and internal audit work which is consistent with the results of our study.

\section{Future Research}

Researchers can study whether outsourced internal audit activities result in greater internal auditor objectivity. Also, other than the direct employment relationship, what are the differences in the relationships between internal auditors and management and external auditors and management and whether these differences in relationships drive differences in objectivity threats? There are no previous academic efforts at devising a framework for managing threats to internal auditor objectivity.

\section{Acknowledgements}

The authors would like to acknowledge the helpful comments received from the editor and the reviewers.

\section{References}

Abdel-khalik, A. R., Snowball, D. A., \& Wragge, J. H. (1983). The effect of certain internal audit variables on planning and external audit program. The Accounting Review, 58(2), 215-217.

American Institute of Certified Public Accountants (AICPA). (1991). Statement on Auditing Standards No. 65. The auditors' consideration of the internal audit function in an audit of financial statements. New York, NY: AICPA.

Arnold Schneider. (2010). Analysis of professional standards and research findings to develop decision aids for reliance on internal auditing. Research in Accounting Regulation, 22, 96-106. http://dx.doi.org/10.1016/j.racreg.2010.07.004

Brody, R. G. (2012). External auditors' willingness to rely on the work of internal auditors: The influence of work style and barriers to cooperation. Advances in Accounting, incorporating Advances in International Accounting, 28, 11-21. http://dx.doi.org/10.1016/j.adiac.2012.02.005

Brody, R. G., Golen, S. P., \& Reckers, P. M. J. (1998). An empirical investigation of the interface between internal and external auditors. Accounting and Business Research, 28(3), 160-172. http://dx.doi.org/10.1080/00014788.1998.9728907

Brown, P. R. (1983). Independent auditor judgment in the evaluation of internal audit functions. Journal of Accounting Research, (Autumn), 444-455. http://dx.doi.org/10.2307/2490784 
Carcello, J. V., Hermanson, D. R., \& Raghunandan, K. (2005). Factors associated with U.S. public companies' investment in internal auditing. Accounting Horizons, 19(2), 69-84. http://dx.doi.org/10.2308/acch.2005.19.2.69

Carey, P., Simnett, R., \& Tanewski, G. (2000). Voluntary demand for internal and external by family businesses. Auditing: A Journal of Practice and Theory, 19(Suppl.).

Clark, M. W., Gibbs, T. E., \& Schroeder, R. G. (1980). Evaluating internal audit departments under SAS No. 9: criteria for judging competence, objectivity, and performance. The Woman CPA, 22, 8-11.

DeZoort, F. T., Houston, R. W., \& Peters, M. F. (2001). The impact of internal auditor compensation and role on external auditors' planning judgments and decisions. Contemporary Accounting Research, Summer, 257-281. http://dx.doi.org/10.1506/7ERQ-LD54-BTQV-TUVE

Elliott, R. K., \& Korpi, A. R. (1978). Factors affecting audit fees. Appendix Commission on Auditors' Responsibilities. Cost-Benefit Analysis of Auditing Research Study No. 3 by Melvin F. Shakun. New York: AICPA.

Felix, W. L., Gramling, A. A., \& Maletta, M. J. (2001). The contribution of internal audit as a determinant of external audit fees and factors influencing this contribution. Journal of Accounting Research, December, 513-53. http://dx.doi.org/10.1111/1475-679X.00026

Francis, J. (1984). The effect of audit firm size on audit prices. Journal of Accounting and Economics, 6, 133-152. http://dx.doi.org/10.1016/0165-4101(84)90010-7

Glover, S. M. (2008). Internal Audit Sourcing Arrangement and the External Auditor's Reliance Decision. Contemporary Accounting Research. http://dx.doi.org/10.1506/car.25.1.7

Goodwin-Stewart, J., \& Kent, P. (2006). The use of internal audit by Australian companies. Managerial Auditing. http://dx.doi.org/10.1108/02686900610634775

Gramling, A. A. (1999). External auditors' reliance on work performed by internal auditors: the influence of fee pressure on this reliance decision. Auditing: a Journal of Practice \& Theory, 18, 117-135.

Gramling, A. A., \& Myers, P. M. (1997). Practitioners' and users' perceptions of the benefits of certification of internal auditors. Accounting Horizons, March, 39-53. Retrieved form http://www.efsa.gov.eg/content/efsa2_ar/efsa2_merge_audit/audit13.htm

Institute of Internal Auditors (IIA). (2003). The IIA's position statement on audit committees.

Institute of Internal Auditors (IIA). (2009). Guidance Task Force. Altamonte Springs, FL. The Institute of Internal Auditors.

Jaggi, B., \& Leung, S. (2007). Impact of family dominance on monitoring of earnings management by audit committees: Evidence from Hong Kong. Journal of International Accounting, Auditing and Taxation, 16, 27-50. http://dx.doi.org/10.1016/j.intaccaudtax.2007.01.003

Jane. (2003). independence and objectivity: a framework for research opportunities in internal auditing. The Institute of Internal Auditors Research Foundation Journal, 21(1), 81-101.

Jenny, G. S. (2006). Relation between external audit fees, audit committee characteristics and internal audit. Accounting and Finance, 46, 387-404. http://dx.doi.org/10.1111/j.1467-629X.2006.00174.x

Kachelmeier, S. J., \& Shehata, M. (1997). Internal auditing and voluntary cooperation in firms: A cross-cultural experiment. The Accounting Review, 72(3), 407-431.

Krishnamoorthy, G. (2001). A cascaded inference model for evaluation of the internal audit report. Decision Sciences, Summer, 499-520. http://dx.doi.org/10.1111/j.1540-5915.2001.tb00969.x

Leung, P. B., \& Cooper, P. R. (2004). The Role of International Audit in Corporate Governance and Management. Melbourne, Vic: RMIT Publishing.

Maletta, M. J. (1993). An examination of auditors' decisions to use internal auditors as assistants: The effect of $\begin{array}{llll}\text { inherent } & \text { risk. Contemporary Accounting }\end{array}$ http://dx.doi.org/10.1111/j.1911-3846.1993.tb00895.x

Margheim, L. L. (1986). Further evidence on external auditors' reliance on internal auditors. Journal of Accounting Research, Spring, 194-205. http://dx.doi.org/10.2307/2490813

Munro, L. (2009). External auditors' reliance on internal audit: the impact of sourcing arrangements and 
$\begin{array}{llll}\text { consulting activities. } & \text { Accounting }\end{array}$ http://dx.doi.org/10.1111/j.1467-629X.2009.00322.x

National Commission on Fraudulent Financial Reporting (Treadway Commission). (1987). Report of the National Commission on Fraudulent Financial Reporting, AICPA, New York.

O'Keefe, T., Simunic, D., \& Stein, M. (1994). The production of audit services: Evidence from a major public accounting firm. Journal of Accounting Research, 32, Autumn, 241-261. http://dx.doi.org/10.2307/2491284

Prawitt, D. F., Smith, J. L., \& Wood, D. A. (2009). Internal audit quality and earnings management. The Accounting Review, 84, 1255-1280. http://dx.doi.org/10.2308/accr.2009.84.4.1255

Public Company Accounting Oversight Board (PCAOB). (2007a). Auditing Standard No. 5. An audit of internal control over financial reporting that is integrated with an audit of financial statements. Retrieved from http://www.pcaobus.org/Rules/Docket_021/2007-05-Release_No_2007-005.pdf

Public Company Accounting Oversight Board (PCAOB). (2007b). Board approves new audit standard for internal control over financial reporting and, separately, recommendations on inspection frequency rule. Retrieved from http://www.pcaobus.com/News_and_Events/News/2007/05-24.aspx

Public Company Accounting Oversight Board (PCAOB). (2007c). An audit of internal control over financial reporting that is integrated with an audit of financial statements. Standard No. 5; PCAOB Release No. 2007-005 (May 24).

Reinstein, A., Lander, G. H., \& Gavin, T. A. (1994). The external auditor's consideration of the internal audit function. Managerial Auditing Journal, 9(7), 29-36. http://dx.doi.org/10.1108/02686909410067570

Sandra, H., \& Marion, H. (2010). Internal audit department characteristics/activities and audit fees: Some evidence from Hong Kong firms. Journal of International Accounting, Auditing and Taxation, 19, 121-136. http://dx.doi.org/10.1016/j.intaccaudtax.2010.07.004

Schneider, A. (1985). The reliance of external auditors on the internal audit function. Journal of Accounting Research, 23(2), 911-919. http://dx.doi.org/10.2307/2490849

Simunic, D. A. (1980). The pricing of audit services: Theory and evidence. Journal of Accounting Research, 18(Spring), 161-190. http://dx.doi.org/10.2307/2490397

The Institute of Internal Auditors Research Foundation (IIARF). (2007). A global summary of the common body of knowledge.

Wallace, W. A. (1984). Internal auditors can cut outside CPA costs. Harvard Business Review, 62, 16-20.

White, H. (1980). A heteroskedasticity-consistent covariance matrix estimator and a direct test for heteroskedasticity. Econometrics, 48, 817-838. http://dx.doi.org/10.2307/1912934

Whittington, A., \& Winters, J. (1990). Considering the work of an internal auditor. The CPA Journal, April, 28-34.

Zain, M. M. (2006). Internal Auditors' Assessment of their Contribution to Financial Statement Audits: The Relation with Audit Committee and Internal Audit Function Characteristics. International Journal of Auditing. http://dx.doi.org/10.1111/j.1099-1123.2006.00306.x

Zulkifflee, M., Mazlina, M., Nava, S., \& Wan, F. (2012). Internal Audit Attributes and External Audit's Reliance on Internal Audit: Implications for Audit Fees. International Journal of Auditing. 